Article

\title{
An Exploratory Analysis of Risks in Green Residential Building Construction Projects: The Case of Singapore
}

\author{
Bon-Gang Hwang ${ }^{1}$, Ming Shan ${ }^{1, *}$, Helena Phua ${ }^{1}$ and Seokho Chi ${ }^{2,3}$ \\ 1 Department of Building, National University of Singapore, Architecture Drive 4, Singapore 117566, \\ Singapore; bdghbg@nus.edu.sg (B.-G.H.); helenaphua20@gmail.com (H.P.) \\ 2 Department of Civil and Environmental Engineering, Seoul National University, 1 Gwanak-Ro, Gwanak-Ku, \\ Seoul 08826, Korea; shchi@snu.ac.kr \\ 3 The Institute of Construction and Environmental Engineering (ICEE), 1 Gwanak-Ro, Gwanak-Ku, \\ Seoul 08826, Korea \\ * Correspondence: bdgsm@nus.edu.sg; Tel.: +65-8319-9008
}

Received: 23 May 2017; Accepted: 24 June 2017; Published: 26 June 2017

\begin{abstract}
Recently, an increasing number of green residential buildings have been developed worldwide owing to active promotion from the authorities and increasing interest from customers. However, in the same way as traditional residential buildings, the construction of green residential buildings faces various risks. The aims of this study are to identify and assess the diverse risks in green residential building construction projects, compare their risk criticalities with those in traditional counterparts, and propose helpful risk mitigation measures. To achieve these goals, a comprehensive literature review was first conducted, and a questionnaire was then administered to 30 construction companies in Singapore. Survey results showed that "complex procedures to obtain approvals", "overlooked high initial cost", "unclear requirements of owners", "employment constraint", and "lack of availability of green materials and equipment" were the top five critical risks in green residential building construction projects. Survey results also showed that green residential building projects were facing risks at a more critical level than those traditional residential building projects. Additionally, this study proposed fourteen risk mitigation measures to tackle the risks in green residential building construction projects. This study has contributed to the body of knowledge by identifying and evaluating the critical risks and mitigation measures in green residential building construction projects. Meanwhile, the findings from this study can also provide an in-depth understanding of risk management in green residential building construction projects to practitioners and thus benefit the practice.
\end{abstract}

Keywords: green residential building construction projects; critical risks; mitigation measures

\section{Introduction}

Today it is widely recognized that human activities are accountable for various global crises such as climate change, resource depletion, and environmental degradation, and one representative of these activities is construction [1-5]. According to the United Nations Environment Program [6], the construction industry has become a big energy consumer who uses 40-50 percent of global energy and 40 percent of global raw materials; and also a principal waste contributor who releases 40 percent of global greenhouse gas emissions and produces 40 percent of solid waste worldwide. These anxiety-provoking numbers exert considerable pressure on policy makers who eventually decide to adopt and promote green buildings [7-9]. Thus, there has been a tremendous growth in green buildings globally recently [7,9-11]. 
The construction industry is a key sector in Singapore. According to the Building and Construction Authority [12], the construction output of Singapore in 2015 was around SGD 36.4 billion (approximately USD 26.8 billion), accounting for 4.7 percent of total Gross Domestic Product of the country. Meanwhile, Singapore is also an active advocate for green buildings. In 2008, Singapore formed an Inter-Ministerial Committee on Sustainable Development that set an ambitious target for the country to have at least 80 percent of buildings going green by 2030 [13]. Since then, Singapore has successively rolled out a host of masterplans and incentive schemes to promote the development of green buildings across the country [14-16].

In a typical densely populated city-state like Singapore, a large number of residential buildings must be built to address people's housing needs [17]. Based on statistics revealed by Building and Construction Authority (BCA, the local government department for building and construction affairs), residential buildings have become the largest ingredient of the local construction market in recent years [18]. Thus, naturally, the residential buildings came to be the primary target for local construction authority to promote green buildings. To date considerable efforts have been devoted in this regard by local authorities. For instance, in 2007, the Housing and Development Board (HDB) began developing environmentally-friendly public housing blocks (e.g., Punggol Eco-Town) in Singapore; and in 2012, HDB got started on retrofitting those existing, old and traditional residential buildings with green and sustainable features [19,20]. Meanwhile, since 2010, BCA has also introduced a suite of regimes like BCA Green Mark for New Residential Buildings and BCA Green Mark for Existing Residential Buildings to regulate the development of green residential buildings in this country $[21,22]$.

Inevitably, construction projects face diverse risks [1,3,11], and the green residential building construction projects are no exception. Particularly, due to extensive use of complicated construction technologies and innovative materials, the risks embedded in green residential building construction projects might be beyond those involved with traditional residential building construction projects. Thus, this study proposed a research hypothesis that the risk criticalities between green and traditional residential building construction projects were different. To test this hypothesis, this study identified the risks of green residential building construction projects, assessed and compared their risk criticalities between green and traditional contexts. Moreover, this study also provided a set of useful risk mitigation measures to tackle the risks in green residential building construction projects.

Although there have been several studies addressing risks in green building construction projects $[1,3,7-9,11,23]$, very few investigated the risks in green residential building construction projects. Therefore, this study can contribute to the body of knowledge of green buildings. Additionally, findings from this study can also enhance practitioners' awareness of risk management in green residential building construction projects, and thus contribute to the industry.

\section{Background}

\subsection{Green Buildings and Green Residential Buildings in Singapore}

Singapore is a city-state with limited natural resources and land area [15], making sustainability a necessity rather than an option to the country. Over the past three decades, Singapore has been struggling to integrate sustainability in its various industries [24], and the construction industry is one of its primary emphases. In 2005, Singapore government kick-started the green building campaign by introducing BCA Green Mark scheme. Since then, this country has successively advanced three rounds of Green Building Masterplans (i.e., Masterplans of 2006, 2009, and 2014) to promote the green building movement in the country [13]. In the meantime, Singapore government has also launched a series of incentive schemes (e.g., Green Mark Incentive Scheme for New Buildings in 2006 and Green Mark Incentive Scheme for Existing Buildings in 2009) to encourage building owners, developers, and contractors to develop and construct more green buildings $[25,26]$. Stimulated by this comprehensive suite of policies and initiatives, the green built environment in Singapore has achieved rapid development, and the numbers of green buildings have increased greatly, from 17 in 2005 to 
over 2,100 in 2014 [13]. Figure 1 presents an overview of the green building initiatives launched by the local authority.

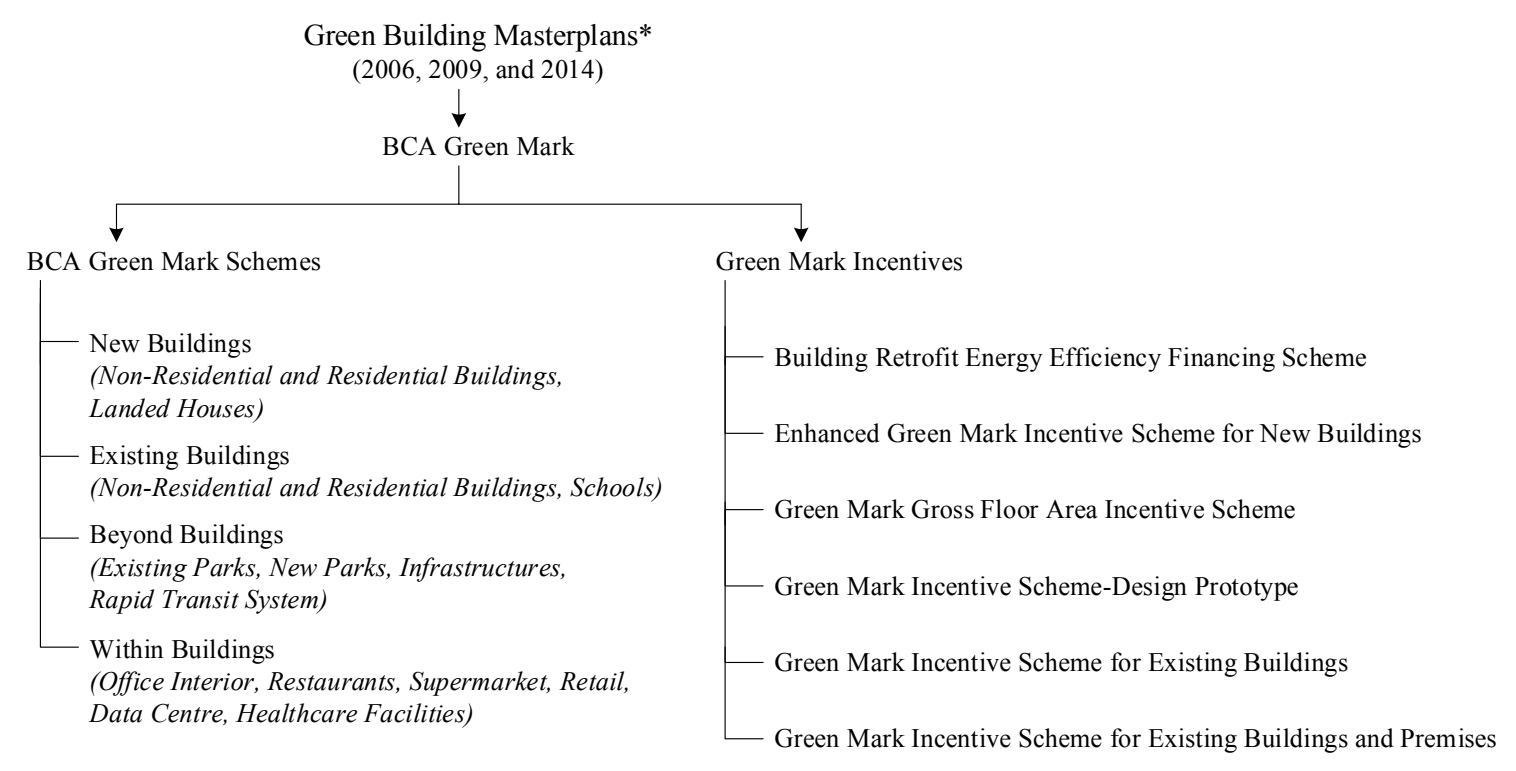

* The figure was created based on the information from BCA.

Figure 1. Overview of the Green Building Initiatives in Singapore.

To reach its ambitious goal of greening 80 percent of buildings in the country, the government of Singapore has also intensified its efforts in the section of residential buildings. In 2010, BCA launched BCA Green Mark for New Residential Buildings to encourage developers, building owners, and architecture firms to develop green and sustainable buildings that can achieve more energy and resource savings [21]. In 2011, BCA launched BCA Green Mark for Existing Residential Buildings further, aiming to help building owners and facility operators retrofit their existing buildings with green and sustainable features [22]. Meanwhile, the local government has also started to develop new sustainable residential blocks. In 2007, the HDB, National Environment Agency, Public Utilities Board, and the Economic Development Board jointly developed the Treelodge@Punggol (Punggol, Singapore), the first eco-precinct in Singapore. This project fully utilized green technologies to ensure the efficient use of energy, materials, and resources and had been awarded the first Green Mark Platinum Award of Singapore [20]. Additionally, in 2012, HDB launched HDB Green Print scheme to retrofit those existing, traditional, and old residential buildings [19]. The relevant retrofitting work under this scheme contained the construction of an automated waste collection system, the installation of photovoltaic modules on rooftops, the enhancement of pedestrian paths and cycling tracks, the installation of secured bicycle parking facilities, and the intensification of greenery around the neighborhood [27]. This scheme has been piloted successfully in Yuhua Estate, Singapore between 2012 and 2015, which has benefited the 3,200 households living in that community [28].

\subsection{Risks in Green Building Construction Projects}

Although particular research of the risks in green residential building construction projects is limited, the relevant research in generic green building construction projects keeps increasing over recent years [8], based on the assumption that risks in generic green building construction projects are also applicable to green residential building construction projects. This section therefore fully reviews the risks in generic green buildings construction projects, aiming to come up with a comprehensive list of risks for green residential building construction projects. 
Current studies have addressed a wide range of risks in generic green building construction projects. Ranaweera and Crawford [2] emphasized that green building construction projects faced a higher financial risk compared to their traditional counterparts because the adoption of the environmental strategies typically required a higher investment which would cause cost overruns to projects. Dewlaney et al. [29] found that the Leadership in Energy and Environmental Design (LEED) certified building projects had put industry practitioners at a higher safety risk. Their research suggested that, compared to those working on non-LEED projects, practitioners working on LEED projects were subject to a 36 percent increment in laceration, sprains, and strains from handling construction materials; a 24 percent increment in falls to lower levels from roof when installing renewable energy apparatuses (e.g., photovoltaic panels); and a 14 percent increment in exposure to toxic substances when positioning innovative wastewater treatment devices. Fortunato et al. [23] expressed similar concerns as their studies also showed that workers on LEED certified projects were exposed to work at height, near unstable soils, with electrical current, and near heavy vehicles and equipment for a longer duration than those working on traditional projects. Tollin [30] stated that green building construction projects confronted a significant risk of failure due to defects and omissions by design professionals, contractors, and subcontractors. Also, Tollin [30] emphasized that owners would face risks of being sued by occupants or tenants, losing tax credit, and losing beneficial financing or loan, if their green building construction projects fail to achieve the expected level of green certification. Zou and Couani [7] summarized 40 risks associated with green building development and conducted a questionnaire survey within the context of Australian construction industry. Their survey results suggested that the top five important risks were a higher investment, lack of commitment in the supply chain, lack of shared information on green building, additional costs in skills development, and lack of expertise regarding green building. Using the approach of Social Network Analysis (SNA), Yang and Zou [8] and Yang, Zou and Wang [9] developed stakeholder-associated risk models to examine the risks in green building construction projects. They found that diverse stakeholders recognized ethical/reputational risks more widely and that technological risks were not important as perceived. Hwang, Zhao, See and Zhong [3] identified and evaluated 20 risk factors in green retrofit projects, and they discussed the top eight risk factors in details, including risks associated with post-retrofit tenants' cooperation, regulations, market demand, project finance, pre-retrofit tenants' cooperation, concerns from stakeholders, material supply and availability, and construction quality. Through a questionnaire survey, Qin, Mo and Jing [11] assessed risks in Chinese green building construction projects and found the top five critical risks were complicated approval procedures due to government bureaucracy, poor maintenance in green buildings, lack of design experience on green buildings, lack of experienced property management for green buildings, and inaccurate green goal established by the owner/developer. Also, Zhao, Hwang and Gao [1] proposed a green building risk framework consisting of 28 risk factors under 11 risk groups. Zhao, Hwang and Gao [1] also developed a fuzzy model to assess these risks, and their assessment results showed that the most critical risk factor was inaccurate cost estimation and that the top critical risk group in green building construction projects was cost overrun. The in-depth review above provided a solid basis for the identification of risks in green residential building construction projects. An initial list of 42 risks and their sources, as well as their original countries, were summarized in Table 1 below. 
Table 1. Diverse risks in green residential building construction projects.

\begin{tabular}{|c|c|c|}
\hline Code & Risks & Sources \\
\hline R1 & Green building policies change & Qin, Mo and Jing [11], China \\
\hline $\mathrm{R} 2$ & Energy saving uncertainty & $\begin{array}{l}\text { Hwang, Zhao, See and Zhong [3], Singapore, Yang and Zou [8], } \\
\text { Australia, and Yang, Zou and Wang [9], Australia }\end{array}$ \\
\hline R3 & Inflation & $\begin{array}{l}\text { Zhao, Hwang and Gao [1], Singapore, Ranaweera and Crawford [2], } \\
\text { Australia, and Zou and Couani [7], Australia }\end{array}$ \\
\hline $\mathrm{R} 4$ & Fluctuation in exchange rates & $\begin{array}{l}\text { Zhao, Hwang and Gao [1], Singapore, Hwang, Zhao, See and Zhong [3], } \\
\text { Singapore, and Zou and Couani [7], Australia }\end{array}$ \\
\hline R5 & High crime rate & Zhao, Hwang and Gao [1], Singapore \\
\hline R6 & $\begin{array}{l}\text { Complex procedures to obtain } \\
\text { approvals }\end{array}$ & $\begin{array}{l}\text { Zhao, Hwang and Gao [1], Singapore, Zou and Couani [7], Australia, } \\
\text { and Qin, Mo and Jing [11], China }\end{array}$ \\
\hline R7 & Safety and health & $\begin{array}{l}\text { Zhao, Hwang and Gao [1], Singapore, Fortunato III, Hallowell, Behm } \\
\text { and Dewlaney [23], U.S.A, and Dewlaney, Hallowell and Fortunato } \\
\text { III [29], U.S.A }\end{array}$ \\
\hline R8 & Employment constraint & $\begin{array}{l}\text { Zhao, Hwang and Gao [1], Singapore, Hwang, Zhao, See and Zhong [3], } \\
\text { Singapore, Zou and Couani [7], Australia, Yang and Zou [8], Australia, } \\
\text { Yang, Zou and Wang [9], Australia, Qin, Mo and Jing [11], China }\end{array}$ \\
\hline R9 & Pollution restrictions & Yang and Zou [8], Australia, and Yang, Zou and Wang [9], Australia \\
\hline R10 & Import/export restrictions & $\begin{array}{l}\text { Hwang, Zhao, See and Zhong [3], Singapore, and Zou and } \\
\text { Couani [7], Australia }\end{array}$ \\
\hline R11 & $\begin{array}{l}\text { Unclear contract conditions for } \\
\text { claims and litigations }\end{array}$ & Zhao, Hwang and Gao [1], Singapore \\
\hline $\mathrm{R} 12$ & $\begin{array}{l}\text { Unclear contract conditions for } \\
\text { dispute resolution }\end{array}$ & $\begin{array}{l}\text { Zhao, Hwang and Gao [1], Singapore, and Hwang, Zhao, See and } \\
\text { Zhong [3], Singapore }\end{array}$ \\
\hline R13 & $\begin{array}{l}\text { Unclear allocation of roles and } \\
\text { responsibilities }\end{array}$ & $\begin{array}{l}\text { Zou and Couani [7], Australia, Yang and Zou [8], Australia, Yang, Zou } \\
\text { and Wang [9], Australia, and Qin, Mo and Jing [11], China }\end{array}$ \\
\hline $\mathrm{R} 14$ & Shortage of funds & $\begin{array}{l}\text { Zhao, Hwang and Gao [1], Singapore, Ranaweera and Crawford [2], } \\
\text { Australia, Hwang, Zhao, See and Zhong [3], Singapore, Yang and } \\
\text { Zou [8], Australia, Yang, Zou and Wang [9], Australia, and Qin, Mo and } \\
\text { Jing [11], China }\end{array}$ \\
\hline R15 & Unclear requirements of owners & $\begin{array}{l}\text { Zhao, Hwang and Gao [1], Singapore, Zou and Couani [7], Australia, } \\
\text { Yang and Zou [8], Australia, Yang, Zou and Wang [9], Australia, and } \\
\text { Qin, Mo and Jing [11], China }\end{array}$ \\
\hline R16 & $\begin{array}{l}\text { Inappropriate interventions } \\
\text { of clients }\end{array}$ & Zhao, Hwang and Gao [1], Singapore \\
\hline R17 & $\begin{array}{l}\text { Loose control over } \\
\text { subcontractors }\end{array}$ & Zhao, See and Zhong [3], Singapore \\
\hline R18 & $\begin{array}{l}\text { Warranties to homeowners of } \\
\text { green building }\end{array}$ & Zhao, See and Zhong [3], Singapore, and Tollin [30], U.S.A. \\
\hline R19 & $\begin{array}{l}\text { Unclear design details and } \\
\text { specifications }\end{array}$ & $\begin{array}{l}\text { Zhao, Hwang and Gao [1], Singapore, Zou and Couani [7], Australia, } \\
\text { Yang and Zou [8], Australia, Yang, Zou and Wang [9], Australia, and } \\
\text { Qin, Mo and Jing [11], China, and Tollin [30], U.S.A. }\end{array}$ \\
\hline $\mathrm{R} 20$ & $\begin{array}{l}\text { Being fined for failing to achieve } \\
\text { Green Mark standards }\end{array}$ & Qin, Mo and Jing [11], and China Tollin [30], U.S.A \\
\hline $\mathrm{R} 21$ & $\begin{array}{l}\text { Poor communication among } \\
\text { projects stakeholders }\end{array}$ & $\begin{array}{l}\text { Zou and Couani [7], Australia, Yang and Zou [8], Australia, Yang, Zou } \\
\text { and Wang [9], Australia, and Qin, Mo and Jing [11], China }\end{array}$ \\
\hline $\mathrm{R} 22$ & $\begin{array}{l}\text { Lack of qualified professionals } \\
\text { with proper design expertise }\end{array}$ & $\begin{array}{l}\text { Zhao, See and Zhong [3], Singapore, Zou and Couani [7], Australia, } \\
\text { Yang and Zou [8], Australia, Yang, Zou and Wang [9], Australia, and } \\
\text { Qin, Mo and Jing [11], China }\end{array}$ \\
\hline $\mathrm{R} 23$ & $\begin{array}{l}\text { Claims of overstated or } \\
\text { unverifiable benefits }\end{array}$ & Tollin [30], U.S.A. \\
\hline $\mathrm{R} 24$ & Unfamiliarity of job requirement & $\begin{array}{l}\text { Zou and Couani [7], Australia, Yang and Zou [8], Australia, Yang, Zou } \\
\text { and Wang [9], Australia, and Qin, Mo and Jing [11], China }\end{array}$ \\
\hline R25 & $\begin{array}{l}\text { Exposed to lawsuit for failing to } \\
\text { achieve GM standards }\end{array}$ & Tollin [30], U.S.A., and Qin, Mo and Jing [11], China \\
\hline R26 & Overlooked high initial cost & Zhao, Hwang and Gao [1], Singapore \\
\hline
\end{tabular}


Table 1. Cont.

\begin{tabular}{|c|c|c|}
\hline Code & Risks & Sources \\
\hline $\mathrm{R} 27$ & Technical Issues & $\begin{array}{l}\text { Zhao, Hwang and Gao [1], Singapore, Zou and Couani [7], Australia, } \\
\text { Yang and Zou [8], Australia, Yang, Zou and Wang [9], Australia, and } \\
\text { Qin, Mo and Jing [11], China }\end{array}$ \\
\hline $\mathrm{R} 28$ & $\begin{array}{l}\text { Lack of availability of green } \\
\text { materials and equipment }\end{array}$ & $\begin{array}{l}\text { Zhao, Hwang and Gao [1], Singapore, Zhao, See and Zhong [3], } \\
\text { Singapore, Zou and Couani [7], Australia, Yang and Zou [8], Australia, } \\
\text { Yang, Zou and Wang [9], Australia, and Qin, Mo and Jing [11], China }\end{array}$ \\
\hline R29 & Lack of technical expertise & $\begin{array}{l}\text { Zhao, See and Zhong [3], Singapore, Zou and Couani [7], Australia, } \\
\text { Yang and Zou [8], Australia, Yang, Zou and Wang [9], Australia, and } \\
\text { Qin, Mo and Jing [11], China }\end{array}$ \\
\hline $\mathrm{R} 30$ & $\begin{array}{l}\text { Unfamiliarity with green } \\
\text { materials and construction } \\
\text { technologies }\end{array}$ & $\begin{array}{l}\text { Zhao, Hwang and Gao [1], Singapore, Zhao, See and Zhong [3], } \\
\text { Singapore, Zou and Couani [7], Australia, Yang and Zou [8], Australia, } \\
\text { Yang, Zou and Wang [9], Australia, and Qin, Mo and Jing [11], China }\end{array}$ \\
\hline R31 & Lack of experience & $\begin{array}{l}\text { Zhao, See and Zhong [3], Singapore, Zou and Couani [7], Australia, } \\
\text { Yang and Zou [8], Australia, Yang, Zou and Wang [9], Australia, and } \\
\text { Qin, Mo and Jing [11], China }\end{array}$ \\
\hline R32 & Setting expectations too high & Zhao, See and Zhong [3], Singapore \\
\hline R33 & Unskilled workers & $\begin{array}{l}\text { Zhao, Hwang and Gao [1], Singapore, Zhao, See and Zhong [3], } \\
\text { Singapore, and Zou and Couani [7], Australia, }\end{array}$ \\
\hline R34 & Poor Design & $\begin{array}{l}\text { Zhao, Hwang and Gao [1], Singapore, Zou and Couani [7], Australia, } \\
\text { Yang and Zou [8], Australia, Yang, Zou and Wang [9], Australia, Qin, } \\
\text { Mo and Jing [11], China, and Tollin [30], U.S.A. }\end{array}$ \\
\hline R35 & Poor Workmanship & $\begin{array}{l}\text { Zhao, See and Zhong [3], Singapore, Zou and Couani [7], Australia, } \\
\text { Yang and Zou [8], Australia, Yang, Zou and Wang [9], Australia, Qin, } \\
\text { Mo and Jing [11], China, and Tollin [30], U.S.A. }\end{array}$ \\
\hline R36 & Inefficient Communication & $\begin{array}{l}\text { Zhao, Hwang and Gao [1], Singapore, Zou and Couani [7], Australia, } \\
\text { Yang and Zou [8], Australia, Yang, Zou and Wang [9], Australia, and } \\
\text { Qin, Mo and Jing [11], China }\end{array}$ \\
\hline R37 & Lack of management staff & Zhao, Hwang and Gao [1], Singapore \\
\hline $\mathrm{R} 38$ & $\begin{array}{l}\text { Unfamiliarity with } \\
\text { construction process }\end{array}$ & $\begin{array}{l}\text { Zhao, See and Zhong [3], Singapore, Zou and Couani [7], Australia, } \\
\text { Yang and Zou [8], Australia, and Yang, Zou and Wang [9], Australia }\end{array}$ \\
\hline R39 & Inaccurate estimation & $\begin{array}{l}\text { Zhao, Hwang and Gao [1], Singapore, Zhao, See and Zhong [3], } \\
\text { Singapore, Zou and Couani [7], Australia, and Qin, Mo and } \\
\text { Jing [11], China }\end{array}$ \\
\hline $\mathrm{R} 40$ & $\begin{array}{l}\text { Unfamiliarity with new } \\
\text { technology rates }\end{array}$ & $\begin{array}{l}\text { Zhao, See and Zhong [3], Singapore, Zou and Couani [7], Australia, } \\
\text { Yang and Zou [8], Australia, and Yang, Zou and Wang [9], Australia }\end{array}$ \\
\hline $\mathrm{R} 41$ & $\begin{array}{l}\text { Fluctuations in } \\
\text { labor/material rates }\end{array}$ & $\begin{array}{l}\text { Zhao, Hwang and Gao [1], Singapore, Zhao, See and Zhong [3], } \\
\text { Singapore Zou and Couani [7], Australia, Qin, Mo and Jing [11], China }\end{array}$ \\
\hline $\mathrm{R} 42$ & $\begin{array}{l}\text { High Target for Green } \\
\text { Mark Rating }\end{array}$ & Qin, Mo and Jing [11], China \\
\hline
\end{tabular}

\subsection{Risk Mitigation Measures in Green Building Construction Projects}

Accompanying the identification of risks are recommendations for risk mitigation measures. Recently, a series of measures have been successively proposed to mitigate risks in green building construction projects. For instance, Ranaweera and Crawford [2] proposed a decision-making tool to assess the potential of incorporating environmental strategies into to the development of building projects, which may alleviate financial risks caused by sustainable design. Tollin [30] recommended that insurance products could be used to minimize financial risks in green building construction projects. To mitigate safety risks of LEED certified projects, Fortunato III, Hallowell, Behm and Dewlaney [23] suggested encouraging the use of prefabrication, because prefabrication allowed workers to assemble green-tech equipment indoors, which could spare workers from ascending and descending ladders and lifting components overhead during installation on site and thus minimize the potential safety hazard. Zou and Couani [7] stated that risks in green building construction projects could be alleviated by strengthening research and development (R\&D), providing professionals 
with proper training and education, and ensuring coordination and information sharing among various contracting parties. After using their SNA-based risk management model to analyze risks in one green education building construction project in Australia, Yang and Zou [8] found that improving communications and interactions among various contracting parties could effectively mitigate risks in green building construction projects. In addition, Hwang, Zhao, See and Zhong [3] recommended a set of special measures to tackle risks in green retrofitting projects, and they highly recommended the following measures, hiring consultants with sufficient experience in managing green building construction projects to mitigate regulatory risk, increasing public awareness of the benefits of green buildings to minimize market risk, using the delivery method of Design \& Build to settle communication issues among various contracting parties, and using equipment and materials that have been sufficiently tested to ensure project quality. Based on the literature review above $[2,3,7,8,23,30]$, this study also compiled a list of 14 measures to mitigate risks in green residential building construction projects. The detailed descriptions are presented in the section of data analysis and discussions.

\section{Research Methods and Data Presentation}

\subsection{Data Collection and Presentation}

As an effective instrument to collect data based on a sample, the technique of questionnaire survey has been commonly adopted in green construction management research $[7-9,11,31,32]$. Thus, likewise, this study administered a questionnaire survey to assess risks and the relevant mitigation measures in green residential building projects in Singapore. 42 risks and 14 risk mitigation measures obtained from the literature review were utilized to form a questionnaire. Subsequently, two industry experts who had at least five years of experiences in both traditional and green building constructions were invited to review the developed questionnaire, focusing on the statement comprehensiveness, readability, and accuracy. Meanwhile, experts were also encouraged to supplement new risks and mitigation measures based on their practice experiences. Referring to feedback from experts, questionnaire was finalized after a few statements were slightly revised and a set of footnotes were supplemented, as shown in Appendix A. The finalized questionnaire consisted of questions meant (1) to profile respondents and their affiliated companies, (2) to assess the likelihood and impact of each risk in both green and traditional residential building construction projects, and (3) to evaluate the effectiveness of the risk mitigation measures. Moreover, open-ended questions were also positioned in the questionnaire, allowing for any supplement of new risks and mitigation measures.

In Singapore, every company that engages in building and construction business is statutorily required to register to BCA. To date, there have been 1897 registered companies in BCA's directory [33], and it can be deemed as a good respondent pool for construction surveys of this country. The population of this study was set to target at the BCA registered construction companies that have experience in both green and traditional building constructions in Singapore. Thus, after a careful check of their work scope and experiences, a total of 100 qualified companies were randomly identified from the BCA directory for data collection. Questionnaires were sent to these companies via email in January and February 2016. Phone calls and email reminders were sent every week when dispatched questionnaires were not returned. Finally, 31 responses were received, with one eliminated due to its low degree of completeness. Thus, the number of valid responses was 30 , representing a response rate of 30 percent. This response rate was aligned with the norm of 20 to 30 percent in most questionnaire surveys in construction engineering and management research [34]. Although the sample size of the survey is not large, it is comparable to numerous previous studies in the domain of sustainable construction [35,36]. Moreover, 30 responses represent the experiences of 30 different companies, which is also representative to reflect the real situation of risk management in green residential building projects in Singapore.

Table 2 profiles the backgrounds of the companies and respondents. It could be noted that the respondent companies comprised various project stakeholders such as consultants, developers, 
contractors, and architecture firms. Moreover, it was noteworthy that 53 percent of respondents had at least five years' experience in traditional residential building construction projects, and 63 percent of respondents had at least three years' experience in green residential building construction projects. These suggested that the respondent panel had the requisite experience to address the research questions of the survey and that the collected data should be representative.

Table 2. Backgrounds of the respondents and their companies.

\begin{tabular}{ccc}
\hline Profile & Frequency & Percentage \\
\hline Company (total = 30) & & \\
Type & 12 & 40.00 \\
Consultancy & 1 & 3.33 \\
Developer & 10 & 33.33 \\
Contractor & 7 & 23.33 \\
Architecture firm & & \\
Respondent (total = 30) & & 3.33 \\
Job title & 1 & 20.00 \\
Project Manager & 6 & 10.00 \\
Architect & 3 & 50.00 \\
Engineer & 15 & 16.67 \\
Quantity Surveyor & 5 & \\
Consultant & & 6.67 \\
Less than one year & 2 & 13.33 \\
1 to 2 years & 4 & 26.67 \\
3 to 4 years & 8 & 36.67 \\
5 to 10 years & 11 & 16.67 \\
More than ten years & 5 & 10.00 \\
Years of experience in traditional residential building projects & & 26.67 \\
Less than one year & 3 & 40.00 \\
1 to 2 years & 8 & 23.33 \\
3 to 4 years & 12 & 0.00 \\
\hline More than ten years & 7 & 0 \\
\hline Years of experience in green residential building projects & & \\
\hline
\end{tabular}

\subsection{Risk Criticality Indices}

During the survey, respondents were requested to assess the likelihood of occurrence (LO) and magnitude of impact (MI) of each risk, based on two five-point Likert rating scales indicated in Table 3.

Table 3. Rating scales for LO and MI.

\begin{tabular}{ccccc}
\hline & \multicolumn{2}{c}{ Likelihood of Occurrence } & \multicolumn{2}{c}{ Magnitude of Impact } \\
\hline LO & Linguistic Terms & $\begin{array}{c}\text { Likelihood of } \\
\text { References (Percentage) }\end{array}$ & MI & Linguistic Terms \\
\hline 1 & Very unlikely & $<20$ & 1 & Very insignificant \\
2 & Unlikely & $20-40$ & 2 & Insignificant \\
3 & Fairly likely & $40-60$ & 3 & Fairly significant \\
4 & Likely & $60-80$ & 4 & Significant \\
5 & Very likely & $>80$ & 5 & Very significant \\
\hline
\end{tabular}

For this study, the LO and MI of each risk were calculated with Equations (1) and (2), respectively.

$$
L O^{i}=\frac{1}{n} \sum_{j=1}^{n} L O_{j}^{i}
$$




$$
M I^{i}=\frac{1}{n} \sum_{j=1}^{n} M I_{j}^{i}
$$

where $n=$ the total number of respondents, $L O^{i}=$ the likelihood assessment of risk $i, L O_{j}^{i}=$ the likelihood assessment of risk $i$ by respondent $j, M I^{i}=$ the magnitude assessment of risk $i$, and $M I_{j}^{i}=$ the magnitude assessment of risk $i$ by respondent $j$.

To depict each risk more comprehensively, this study used the risk criticality (RC) index to gauge each risk. This RC index has been widely used in risk management-related studies [3,37-42], and can be calculated using the following equations:

$$
\begin{gathered}
R C_{j}^{i}=L O_{j}^{i} \times M I_{j}^{i} \\
R C^{i}=\frac{1}{n} \sum_{j=1}^{n} R C_{j}^{i}
\end{gathered}
$$

where $n=$ the total number of respondents, $R C_{j}^{i}=$ the risk criticality of risk $i$ by respondent $j$, and $R C^{i}=$ the risk criticality of risk $i$. As the assessments of LO and MI were both carried out with a five-point rating system, the RC is thus on a full scale of 25 . This study also established a benchmark of 9 to identify critical risks, which was determined by the product of the median values of LO and MI rating scales as shown in Equation (5). Under this benchmark, risks with RC values above nine were considered as critical risks in green residential building projects, and their distributions were in Zone A as shown in Figure 2.

$$
\begin{array}{r}
\text { Benchmark for Critical Risk }=\text { Median Value of LO rating scale }(\text { i.e., 3) } \times \\
\text { Median Value of MI rating scale }(\text { i.e., 3) }=9
\end{array}
$$

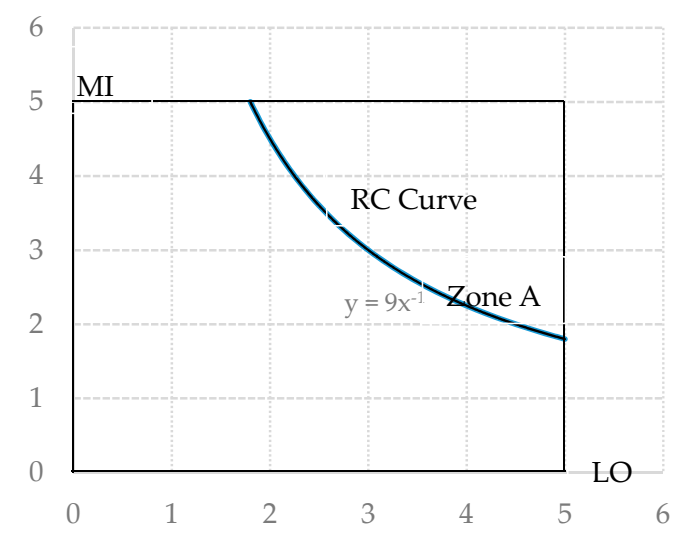

Figure 2. RC curve for the critical risks in green residential building construction projects.

\section{Data Analysis and Discussion}

\subsection{Likelihood, Impact, and Criticality of Risks in Green Residential Building Construction Projects}

Before analyzing the data, Cronbach's alpha was calculated to check data's internal consistency or reliability. Following the instruction of Nunnally, et al. [43], the alpha should be at least 0.7 for a scale to be reliable. In this study, the alpha values of $\mathrm{LO}$ and MI in green residential building construction projects were 0.956 and 0.957 , respectively, indicating that the data collected from the questionnaire survey were of sufficient reliability.

Using Equations (1) through (4), this study calculated the LO, MI, and RC values of each risk and presented them in Table 4 . Regarding the LO values, 28 risks were assessed above 3, suggesting they were fairly likely to occur in green residential building construction projects. In particular, the top five 
risks in LO values were "R6-Complex procedures to obtain approvals", "R26-Overlooked high initial cost", "R15-unclear requirements of owners", "R8-employment constraint", and "R27-technical issues". As for the MI values, 37 risks received MI values above 3, suggesting they had fairly significant impacts on green residential building construction projects. In particular, the top five most impactful risks were "R6-Complex procedures to obtain approvals", "R26-Overlooked high initial cost", "R24-Unfamiliarity of job requirement", "R28-Lack of availability of green materials and equipment", and "R14-Shortage of funds". Regarding RC values, 35 risks scored above 9, suggesting they were critical risks in green residential building construction projects. In particular, the top five critical risks were "R6-Complex procedures to obtain approvals", "R26-Overlooked high initial cost", "R15-Unclear requirements of owners", "R8-Employment constraint", and "R28-Lack of availability of green materials and equipment". The RC values of these five risks are all greater than 14 , indicating that they were extremely critical to green residential building construction projects.

Table 4. Assessments of risks in green residential building construction projects.

\begin{tabular}{|c|c|c|c|c|c|c|}
\hline \multirow{2}{*}{ Code } & \multicolumn{2}{|c|}{ RC } & \multicolumn{2}{|c|}{ LO } & \multicolumn{2}{|c|}{ MI } \\
\hline & Mean & Rank & Mean & Rank & Mean & Rank \\
\hline R6 & 17.27 & 1 & 4.20 & 1 & 4.00 & 1 \\
\hline R26 & 16.67 & 2 & 4.13 & 2 & 3.97 & 2 \\
\hline R15 & 15.07 & 3 & 3.90 & 3 & 3.73 & 6 \\
\hline R8 & 14.47 & 4 & 3.83 & 4 & 3.73 & 6 \\
\hline R28 & 14.17 & 5 & 3.57 & 6 & 3.80 & 4 \\
\hline R22 & 13.53 & 6 & 3.53 & 8 & 3.70 & 8 \\
\hline R24 & 13.50 & 7 & 3.37 & 14 & 3.87 & 3 \\
\hline R27 & 13.00 & 8 & 3.70 & 5 & 3.40 & 14 \\
\hline R19 & 12.87 & 9 & 3.53 & 8 & 3.43 & 12 \\
\hline R40 & 12.77 & 10 & 3.57 & 6 & 3.40 & 14 \\
\hline R41 & 12.63 & 11 & 3.40 & 12 & 3.50 & 11 \\
\hline R33 & 12.23 & 12 & 3.47 & 11 & 3.30 & 22 \\
\hline $\mathrm{R} 42$ & 12.00 & 13 & 3.40 & 12 & 3.40 & 14 \\
\hline R36 & 11.83 & 14 & 3.20 & 20 & 3.53 & 10 \\
\hline R29 & 11.67 & 15 & 3.33 & 16 & 3.37 & 20 \\
\hline R39 & 11.57 & 16 & 3.37 & 14 & 3.30 & 22 \\
\hline R20 & 11.53 & 17 & 3.13 & 25 & 3.23 & 26 \\
\hline R14 & 11.50 & 18 & 2.97 & 29 & 3.77 & 5 \\
\hline R25 & 11.43 & 19 & 3.03 & 28 & 3.60 & 9 \\
\hline R34 & 11.37 & 20 & 3.27 & 18 & 3.43 & 12 \\
\hline R31 & 11.33 & 21 & 3.23 & 19 & 3.20 & 30 \\
\hline R7 & 11.30 & 22 & 3.20 & 20 & 3.40 & 14 \\
\hline R30 & 11.23 & 23 & 3.53 & 8 & 3.00 & 37 \\
\hline R38 & 11.17 & 24 & 3.30 & 17 & 3.23 & 26 \\
\hline R32 & 11.00 & 25 & 3.20 & 20 & 3.17 & 32 \\
\hline $\mathrm{R} 4$ & 10.97 & 26 & 3.10 & 27 & 3.23 & 26 \\
\hline $\mathrm{R} 9$ & 10.63 & 27 & 3.17 & 23 & 3.20 & 30 \\
\hline R12 & 10.60 & 28 & 3.13 & 25 & 3.27 & 25 \\
\hline R11 & 10.27 & 29 & 2.93 & 30 & 3.40 & 14 \\
\hline R35 & 10.03 & 30 & 3.17 & 23 & 3.10 & 36 \\
\hline R21 & 9.87 & 31 & 2.90 & 32 & 3.33 & 21 \\
\hline R37 & 9.83 & 32 & 2.80 & 34 & 3.17 & 32 \\
\hline R3 & 9.80 & 33 & 2.93 & 30 & 3.13 & 35 \\
\hline R23 & 9.73 & 34 & 2.87 & 33 & 3.40 & 14 \\
\hline R17 & 9.13 & 35 & 2.77 & 35 & 2.97 & 38 \\
\hline R18 & 8.93 & 36 & 2.77 & 35 & 2.90 & 39 \\
\hline R10 & 8.93 & 36 & 2.60 & 38 & 3.30 & 22 \\
\hline R16 & 8.63 & 38 & 2.77 & 35 & 2.87 & 40 \\
\hline R13 & 7.60 & 39 & 2.40 & 39 & 2.77 & 41 \\
\hline $\mathrm{R} 2$ & 7.47 & 40 & 2.23 & 40 & 3.17 & 32 \\
\hline R1 & 6.10 & 41 & 1.87 & 41 & 3.23 & 26 \\
\hline R5 & 3.37 & 42 & 1.50 & 42 & 1.90 & 42 \\
\hline
\end{tabular}


The risk "R6-Complex procedures to obtain approvals" occupied the top position in the risk ranking with a $\mathrm{RC}$ value of 17.27 , owing to its highest $\mathrm{LO}$ and $\mathrm{MI}$ values. This was because green residential building projects always involve some particular green features (e.g., solar photovoltaic system, pneumatic waste conveyance system, and rain harvesting system), which would result in lengthier planning approval and permit procedures [1]. Shiers, et al. [44] also identified this risk in the context of green building construction projects and labeled it an "extra step" that wasted considerable time and caused serious disturbances. Moreover, the long processing time for obtaining approval would compromise the on-time delivery of green residential building construction projects and thus increase the likelihood of liquidated damages and poor product quality [7]. This risk has also been assessed as the most critical risk in Chinese green building projects by Qin, Mo and Jing [11].

The risk "R26-Overlooked high initial cost" was ranked second with a RC value of 16.67, attributed to its second highest LO and MI values. Compared to traditional residential building construction projects, green residential building construction projects frequently involve high initial costs that could be attributable to enormous up-front costs of green technologies and materials and additional consultancy services $[7,45]$. However, this issue is often ignored by industry practitioners in Singapore when they estimate costs for green residential building construction projects. This was probably because the green building construction industry of Singapore was still at its early stage and many local industry practitioners haven't yet gained enough experience in addressing green building business. This result echoed findings from Robichaud and Anantatmula [46] who also stressed that high initial cost was a significant barrier to the promotion of green buildings.

The risk "R15-Unclear requirements of owners" received the third position with a RC value of 15.07. This risk received the third highest LO, suggesting that it had a high chance of coming about. Owing to insufficient experiences and knowledge, owners of green residential buildings might not be able to give clear and specific requirements to designers and contractors [1], which could increase risks in projects inevitably. For instance, the unclear requirements from the clients might result in designers' misinterpretation or misunderstanding of the clients' real purposes, which would lead to numerous design changes and considerable reworks eventually. This result also echoed Hwang, Zhao and Tan [15] who recognized unclear requirements of owners as a critical issue affecting the performances of green building construction projects in Singapore.

The risk "R8-Employment constraint" was ranked fourth with a RC value of 14.47. Being a country with limited human resources, Singapore is always leveraging on foreign workforces to ensure its economic growth [47]. Nonetheless, the Singapore government has established some control mechanisms to regulate the number of foreign workers to avoid the local Singaporeans being priced out of the job market. Unfortunately, foreign workforces with green residential building construction experiences are categorized by the Ministry of Manpower Singapore as the unskilled or semi-skilled workforce, which are precisely under the strict control on issuing work permit [48]. Thus, the constructions of local green residential building projects might face a lack of sufficient workforce because of this employment constraint.

The risk "R28-Lack of availability of green materials and equipment" was assessed as the fifth most critical risk with a RC value of 14.17 . It has been widely recognized that adequate material and equipment supply was an important determinant of any successful construction projects, and shortage of material and equipment would jeopardize the success of projects [49]. In Singapore, the majority of construction equipment, materials and even plants designated for green residential building construction projects need to be imported from overseas, which normally requires a long period to be delivered on site $[1,50]$. Therefore, any hang-up relating to the delivery of imported equipment and materials, especially for those referring to the critical activities in project scheduling, would significantly affect the successful delivery of the project. Such a result was in line with the findings from Zhao, Hwang and Gao [1] who also emphasized that availability of materials and equipment was a significant risk requiring additional attention in green building construction projects. 


\subsection{Risk Criticalities: Green versus Traditional Residential Building Construction Projects}

This study also requested respondents to rate the LO and MI of the 42 risks in the context of traditional residential building construction projects in Singapore. Thus, the RC values of the 42 risks in traditional residential building construction projects were also calculated and then compared with those in green ones, as shown in Table 5.

Table 5. Comparison of RC values between green and traditional residential building construction projects.

\begin{tabular}{|c|c|c|c|c|c|c|}
\hline \multirow{2}{*}{ Code } & \multicolumn{2}{|c|}{ Green } & \multicolumn{2}{|c|}{ Traditional } & \multicolumn{2}{|c|}{ Wilcoxon signed-Rank Test } \\
\hline & RC & Rank & $\mathrm{RC}$ & Rank & Difference & $p$-Value \\
\hline R6 & 17.27 & 1 & 9.73 & 2 & 7.54 & $0.000 *$ \\
\hline R26 & 16.67 & 2 & 8.60 & 9 & 8.07 & $0.000 *$ \\
\hline R15 & 15.07 & 3 & 8.40 & 13 & 6.67 & $0.000 *$ \\
\hline R8 & 14.47 & 4 & 10.00 & 1 & 4.47 & 0.000 * \\
\hline $\mathrm{R} 28$ & 14.17 & 5 & 7.40 & 23 & 6.77 & $0.000 *$ \\
\hline $\mathrm{R} 22$ & 13.53 & 6 & 5.50 & 32 & 8.03 & 0.000 * \\
\hline $\mathrm{R} 24$ & 13.50 & 7 & 7.10 & 25 & 6.4 & 0.000 * \\
\hline $\mathrm{R} 27$ & 13.00 & 8 & 7.53 & 22 & 5.47 & 0.000 * \\
\hline R19 & 12.87 & 9 & 7.63 & 21 & 5.24 & 0.000 * \\
\hline R40 & 12.77 & 10 & 8.00 & 16 & 4.77 & 0.000 * \\
\hline R41 & 12.63 & 11 & 9.57 & 3 & 3.06 & 0.000 * \\
\hline R33 & 12.23 & 12 & 9.27 & 5 & 2.96 & 0.004 * \\
\hline $\mathrm{R} 42$ & 12.00 & 13 & 6.20 & 28 & 5.8 & 0.000 * \\
\hline R36 & 11.83 & 14 & 9.30 & 4 & 2.53 & $0.021 *$ \\
\hline R29 & 11.67 & 15 & 6.43 & 27 & 5.24 & 0.000 * \\
\hline R39 & 11.57 & 16 & 9.13 & 6 & 2.44 & 0.001 * \\
\hline R20 & 11.53 & 17 & 4.70 & 35 & 6.83 & 0.000 * \\
\hline R14 & 11.50 & 18 & 8.33 & 14 & 3.17 & 0.000 * \\
\hline $\mathrm{R} 25$ & 11.43 & 19 & 6.03 & 29 & 5.4 & 0.000 * \\
\hline R34 & 11.37 & 20 & 8.27 & 15 & 3.1 & 0.002 * \\
\hline R31 & 11.33 & 21 & 6.03 & 29 & 5.3 & 0.000 * \\
\hline R7 & 11.30 & 22 & 9.27 & 5 & 2.03 & 0.030 * \\
\hline $\mathrm{R} 30$ & 11.23 & 23 & 5.87 & 31 & 5.36 & 0.000 * \\
\hline R38 & 11.17 & 24 & 8.40 & 13 & 2.77 & 0.013 * \\
\hline R32 & 11.00 & 25 & 8.50 & 12 & 2.5 & 0.011 * \\
\hline $\mathrm{R} 4$ & 10.97 & 26 & 7.70 & 19 & 3.27 & 0.034 * \\
\hline R9 & 10.63 & 27 & 8.53 & 11 & 2.1 & 0.051 \\
\hline R12 & 10.60 & 28 & 8.57 & 10 & 2.03 & 0.000 * \\
\hline R11 & 10.27 & 29 & 7.93 & 17 & 2.34 & 0.003 * \\
\hline R35 & 10.03 & 30 & 9.00 & 8 & 1.03 & 0.168 \\
\hline R21 & 9.87 & 31 & 9.10 & 7 & 0.77 & 0.325 \\
\hline R37 & 9.83 & 32 & 7.53 & 22 & 2.3 & 0.011 * \\
\hline R3 & 9.80 & 33 & 7.87 & 18 & 1.93 & $0.003 *$ \\
\hline $\mathrm{R} 23$ & 9.73 & 34 & 6.60 & 26 & 3.13 & 0.001 * \\
\hline R17 & 9.13 & 35 & 7.67 & 20 & 1.46 & 0.002 * \\
\hline R18 & 8.93 & 36 & 5.37 & 34 & 3.56 & 0.000 * \\
\hline R10 & 8.93 & 36 & 6.60 & 26 & 2.33 & 0.003 * \\
\hline R16 & 8.63 & 38 & 6.20 & 28 & 2.43 & 0.015 * \\
\hline R13 & 7.60 & 39 & 7.27 & 24 & 0.33 & 0.916 \\
\hline $\mathrm{R} 2$ & 7.47 & 40 & 6.00 & 30 & 1.47 & 0.137 \\
\hline R1 & 6.10 & 41 & 5.47 & 33 & 0.63 & 0.059 \\
\hline R5 & 3.37 & 42 & 3.03 & 36 & 0.34 & 0.776 \\
\hline
\end{tabular}

${ }^{*}$ The Wilcoxon signed-rank test is significant at the 0.05 significance level.

To look into possible differences in RC values between green and traditional residential building construction projects, the Wilcoxon signed-rank test was conducted. This method is a non-parametric statistical test to compare two sets of scores that come from the same participants, without requiring 
the data must be normally distributed [51]. In this study, test results showed that the $p$-values of 35 risks were less than 0.05 , suggesting there were significant differences in $\mathrm{RC}$ values of the most risks between green and traditional residential building construction projects. These results meant that the hypothesis of this study, namely, risk criticalities between green and traditional residential building projects were different, was supported. Moreover, the RC values of these 35 risks in green residential building construction projects were statistically greater than those in traditional residential building construction projects, implying that green residential building construction projects are facing risks at a more critical level.

The risk "R26-Overlooked high initial cost" received the greatest difference between the two types of projects. The $\mathrm{RC}$ value of this risk in green residential building construction projects (i.e., 16.67) is almost two times of that in traditional residential building construction projects (i.e., 8.60). This was probably because, compared to traditional residential building construction projects, green residential building construction projects requires considerable upfront expenditures on green technologies, materials, and equipment [45]. This result was also supported by Zou and Couani [7] who claimed that the perceived higher upfront costs were the largest obstacle to green building development.

The risk "R22-Lack of qualified professionals with proper design expertise" received the second greatest difference in RCs. This risk received a high rank in green residential building construction projects (i.e., 6), but a low rank in traditional residential building construction projects (i.e., 32), implying that it was more critical to green residential building construction projects. This might be because, compared to those traditional ones, green residential building construction projects require skilled design professionals to handle specialized green and sustainable designs; while the reality in Singapore is that competent and experienced local green design professionals are extremely deficient [3]. Furthermore, the Ministry of Manpower of Singapore has recently increased foreigner worker levies and cut quotas of foreign workforces in the construction industry [52], which even aggravated the unavailability of the competent workforce in this regard.

The risk "R6-Complex procedures to obtain approvals" obtained the third greatest difference in RCs. Although this risk received high ranks in both groups, its RC values were significantly different between two types of projects: 17.27 with green versus 9.73 with traditional. This result could be explained by the fact that green residential building construction projects involve more innovative technologies, materials, and equipment compared to traditional construction projects. Thus, it has to undergo a stricter approval process imposed by the construction authority [1,7], which inevitably makes the processing time longer than that for traditional residential building construction projects.

The risk "R20-Being fined for failing to achieve Green Mark standards" received the fourth greatest difference in the RC assessment, and in particular, its RC value in green residential building construction projects (i.e., 11.53) was much higher than that in traditional ones (i.e., 4.70). In fact, this is a unique risk of green residential building construction projects. In Singapore, the Building Act has required that any new buildings and existing ones that undergo major retrofitting must achieve the minimum Green Mark Certified Level; otherwise, a certain amount of fines will be imposed [53]. For instance, building owners can be subject to a fine up to SGD 100,000 if they fail to achieve the minimum Green Mark standard in their installation of a new cooling system [54].

The risk "R28-Lack of availability of green materials and equipment" was ranked fifth in RC difference. This risk received a low rank (i.e., 23rd) in traditional residential building construction projects, but a high rank (i.e., 5 th) in green ones. This was probably because the green construction industry in Singapore was a young industry and thus the supply of green materials and equipment might be still limited; in contrast, the traditional construction industry had already been fully mature, and thus the common materials and equipment were more widely available comparatively [3]. This result was also in line with Hwang and Leong [50] who argued that material supply and availability was more critical in green building construction projects compared to traditional building construction projects. 


\subsection{Proposed Mitigation Measures}

This study also asked respondents to evaluate the effectiveness of the 14 risk mitigation measures (RMMs) generated from literature. As Table 6 shows, all 14 risk mitigation measures received mean values higher than 3 , indicating all of them were effective in tackling risks in green residential construction building projects in Singapore. Those mitigation measures that received evaluations above four are discussed as follows.

Table 6. Risk mitigation measures in green residential building construction projects in Singapore.

\begin{tabular}{clcc}
\hline Code & \multicolumn{1}{c}{ Risk mitigation measure } & Mean & Rank \\
\hline RMM10 & Improving communication and coordination among contracting parties & 4.57 & 1 \\
RMM12 & Understanding owner's goal of the Green Mark Standard & 4.27 & 2 \\
RMM13 & Using past successful green residential projects as references & 4.20 & 3 \\
& Developing training programs to upgrade workers' skills and knowledge of new & 4.20 & 3 \\
RMM & technologies and materials & 4.13 & 5 \\
RMM6 & Allowing for contingency funds & 3.90 & 6 \\
RMM9 & Fevoting adequate resources to planning and research & 3.83 & 7 \\
RMM2 & Communicating about targeted green mark rating and ways to achieve that with & 3.77 & 8 \\
RMM3 & a clear roles and responsibilities chart & 3.67 & 9 \\
RMM4 & Contract language to be precise and give provision to limit each parties' liabilities & 3.53 & 10 \\
RMM11 & Implementing passive design instead of complicated active building design & 3.50 & 11 \\
RMM7 & Enhanced communication tool for better collaboration (e.g., BIM software) & 3.4 & 12 \\
RMM14 & Working with experienced insurance agent to receive better coverage protection & 3.30 & 13 \\
RMM8 & Effective change management & 3.10 & 14 \\
\hline
\end{tabular}

The risk mitigation measure "RMM10-Improving communication and coordination among contracting parties" was assessed as the most effective measure with the highest evaluation of 4.57. To ensure the success of a green residential building construction project, a higher level of communication is demanded among the contracting parties as compared with traditional residential building construction projects. This is because green residential building construction projects normally require a multidisciplinary team with a more comprehensive professional composition to handle those complicated and innovative technologies, equipment, and materials adopted in such projects [8]. Any information isolation among team members will probably raise various issues such as rework, delay, and cost overrun. This result was also in line with Hwang and Tan [45] who stated that project team's communication was an effective solution to overcome obstacles in green building construction projects.

The risk mitigation measure "RMM12-Understanding owner's goal of the Green Mark Standard" received the second highest value (i.e., 4.27) in the effectiveness evaluation. In Singapore, each new residential building is mandatory to achieve some Green Mark Standard [53]. Thus, it is crucial for the designer, consultant, and contractor to understand owner's goal of Green Mark Standard for the building before they start working on the project. Any negligence or misunderstanding of owner's Green Mark goal can cause the project not to achieve the due green certification and can cause considerable disputes, claims and liquidated damages [11,30]. Zou and Couani [7] obtained the similar conclusion that communicating green building objectives clearly to all the project team members is vital to secure the success of a green building construction project.

The risk mitigation measure "RMM13-Using past successful green residential projects as references" was assessed as the third most effective measure with an evaluation of 4.20 . Referring to successful experiences of past projects is an effective measure to mitigate risks in new construction projects $[55,56]$. So far, Singapore has accumulated some valuable experiences in developing green residential buildings since it introduced the Green Mark for Residential Buildings in 2011 [57]. These experiences can render considerable help to new green residential building construction projects in mitigating risks and achieving a better project performance. This result was comparable to Zou and 
Couani [7] who stated that experience accumulation was an important strategy to reduce risks in green building supply chain.

The risk mitigation measure "RMM5-Developing training programs to upgrade workers' skill and knowledge of new technologies and materials" was also assessed as the third most effective measure with a value of 4.20. During constructions of green building projects, one major issue is that frontline workers might be unfamiliar with innovative technologies and materials adopted in such projects $[45,58]$. Thus, it is crucial to develop a series of training programs for those frontline workers and make sure that they are well trained and informed of the green technologies they are about to use. Currently, the BCA has rolled out some green courses (e.g., Green Mark Professional course and Green Mark Facilities Professional course) to help the local industry advance their knowledge and capability in undertaking green building construction projects, which are very popular with local construction community [14].

The risk mitigation measure "RMM1-Allowing for contingency funds" received the fourth highest value (i.e., 4.13) in the effectiveness evaluation. This risk mitigation measure was highlighted as the complex nature of green residential building construction projects makes the exact budget of the project impossible to forecast accurately. Also, innovative and complicated green technologies adopted in green residential building construction projects might require additional tests and inspections [58], which would also lead to additional cost beyond the original project estimation. Therefore, it is extremely necessary to set aside some contingency funds to entail some unexpected but possible risks. In fact, contingency funds have also been used widely by traditional construction projects to manage their risks [59-61].

\section{Conclusions and Recommendations}

Green residential buildings have achieved a rapid development over recent years due to its positive efficacy of saving energy and resources consumptions. However, risks embedded in the construction of green residential buildings are not adequately addressed. Thus, this study conducted an exploratory research to investigate risks and the relevant mitigation measures in green residential building construction projects.

A total of 42 risks and 14 mitigation measures were identified from a comprehensive literature review first and then included in a questionnaire that was administered to 30 Singapore-based construction companies. Survey results showed that the top five critical risks in green residential building projects were "complex procedures to obtain approvals", "overlooked high initial cost", "unclear requirements of owners", "employment constraint", and "lack of availability of green materials and equipment". Survey results also revealed that 35 out of 39 identified risks obtained significantly higher assessments in green residential building construction projects than in traditional residential building construction projects, suggesting that they are more critical in the former. Moreover, survey results presented the top five most effective risk mitigation measures in green residential building construction projects, and they were "improving communication and coordination among contracting parties", "understanding owner's goal of the Green Mark Standard", "using past successful green residential projects as references", "developing training programs to upgrade workers' skill and knowledge of new technologies and materials", and "allowing for contingency funds".

In spite of the detailed investigation of critical risks and the relevant risk mitigation measures in green residential building construction projects, some limitations are still present in this study. First, the sample size of the survey in this study is relatively small. Thus, cautions should be given when the analysis results are interpreted and generalized. Second, the risk criticality index calculated in this study is subjective to a certain extent and may be biased subject to individual experience and risk preference. Third, findings from this study apply to Singapore exclusively, which may vary in other different countries.

This is the first time various risks and the relevant mitigation measures in green residential building construction projects are systematically investigated by a research initiative. Thus, despite 
limitations mentioned above, findings from this study are still valuable. Also, as findings from this study are actually the firsthand experience gathered from industry practitioners from Singapore, a widely recognized pioneer and global leader in the area of green building construction [36]. Thus, this study should also be useful to other countries that are about to promote green residential buildings and can help them achieve an improved risk management in such type of projects. For instance, relying on findings from this study, industry practitioners in other countries can gain a deeper understanding of risks in green residential building construction projects, develop a customized risk check list for their own green residential building construction projects, and also may come up with some more effective strategies to address these risks.

For further research actions, an assessment model that assesses the risk index in green residential building construction projects can be developed. Also, from the risk mitigation measure perspective, an analytical framework of risks in green residential building construction projects can be established so that none of the risks will be ignored when developing relevant risk mitigation measures. Moreover, it would also be very interesting and necessary to do a comparison of risk mitigation measures between green and traditional residential building projects, because this process can help identify unique mitigation measures for green residential building projects.

Acknowledgments: This work was partially supported by the Korean Federation of Science and Technology Societies (KOFST) grant funded by the Korean government (MSIP: Ministry of Science, ICT, and Future Planning).

Author Contributions: Bon-Gang Hwang conceived and designed the entire study; Helena Phua collected the data; Ming Shan analyzed the data; Ming Shan and Helena Phua wrote the paper; Seokho Chi contributed to the discussion of the results.

Conflicts of Interest: The founding sponsors had no role in the design of the study; in the collection, analyses, or interpretation of data; in the writing of the manuscript, and in the decision to publish the results.

\section{Appendix A. Questionnaire Used for This Study}

\section{Section 1: Background Information of Respondent}

1. Please select the type of your company
A. Consultancy
B. Developer
C. Contractor
D. Architecture firm

2. Please identify your job title
A. Project Manager
B. Architect
C. Engineer
D. Quantity Surveyor
E. Consultant

3. Please identify your years of experience in traditional residential building construction projects
A. Less than one year
B. 1 to 2 years
C. 3 to 4 years
D. 5 to 10 years
E. More than ten years

4. Please identify your years of experience in green residential building construction projects
A. Less than one year 
B. 1 to 2 years

C. 3 to 4 years

D. 5 to 10 years

E. More than ten years

\section{Section 2: Assessment for Risks of Green Residential Building Construction Projects}

Based on your experience in green residential building construction projects, please assess each risk below regarding its likelihood of occurrence and magnitude of impact, using following rating scales:

Likelihood of occurrence: 1-Very unlikely; 2-Unlikely; 3-Fairly likely; 4-Likely; 5-Very likely.

Magnitude of impact: 1-Very insignificant; 2-Insignificant; 3-Fairly significant; 4-Significant; 5-Very significant.

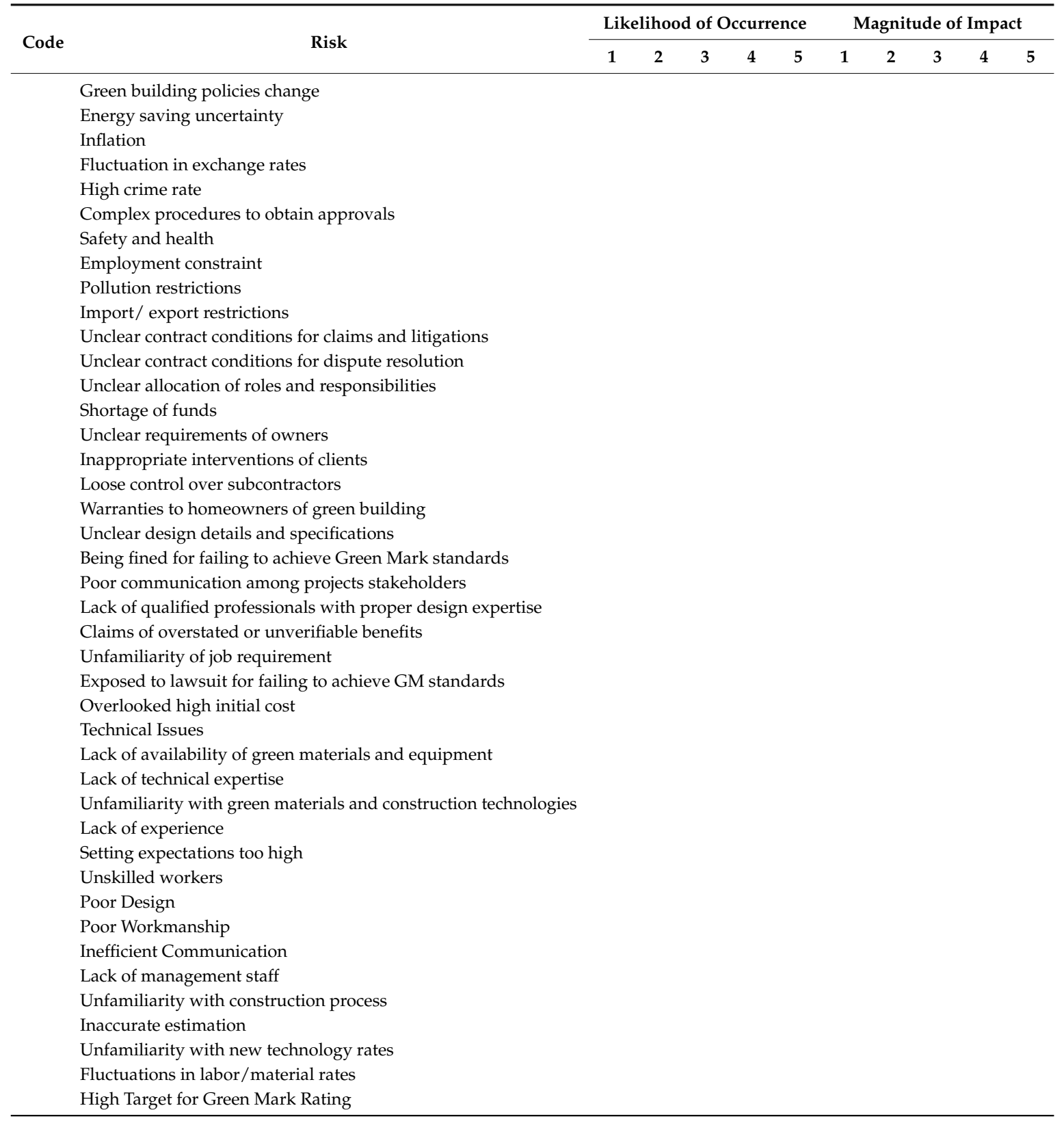

If there is any risk omitted by this questionnaire, please specify and assess it: 


\section{Section 3: Assessment for Risk Mitigation Measures for Green Residential Building Construction Projects}

Based on your experience in green residential building construction projects, please assess the following risk mitigation measures in terms of their effectiveness, using following rating scale:

1-Totally ineffective; 2-Ineffective; 3-Neutral; 4-Effective; 5-Very effective.

\begin{tabular}{|c|c|c|c|c|c|c|}
\hline \multirow{2}{*}{ Code } & \multirow{2}{*}{ Risk Mitigation Measure } & \multicolumn{5}{|c|}{ Effectiveness } \\
\hline & & 1 & 2 & 3 & 4 & 5 \\
\hline RMM1. & Allowing for contingency funds & & & & & \\
\hline RMM2. & $\begin{array}{l}\text { Communicating about targeted green mark rating and } \\
\text { ways to achieve that with a clear roles and } \\
\text { responsibilities chart }\end{array}$ & & & & & \\
\hline RMM3. & $\begin{array}{l}\text { Contract language to be precise and give provision to } \\
\text { limit each parties' liabilities }\end{array}$ & & & & & \\
\hline RMM4. & Constant design evaluation and verifications & & & & & \\
\hline RMM5. & $\begin{array}{l}\text { Developing training programs to upgrade workers' skills } \\
\text { and knowledge of new technologies and materials }\end{array}$ & & & & & \\
\hline RMM6. & Devoting adequate resources to planning and research & & & & & \\
\hline RMM7. & $\begin{array}{l}\text { Enhanced communication tool for better collaboration } \\
\text { (e.g., BIM software) }\end{array}$ & & & & & \\
\hline RMM8. & Effective change management & & & & & \\
\hline RMM9. & Front end planning & & & & & \\
\hline RMM10. & $\begin{array}{l}\text { Improving communication and coordination among } \\
\text { contracting parties }\end{array}$ & & & & & \\
\hline RMM11. & $\begin{array}{l}\text { Implementing passive design instead of complicated } \\
\text { active building design }\end{array}$ & & & & & \\
\hline RMM12. & Understanding owner's goal of the Green Mark Standard & & & & & \\
\hline RMM13. & $\begin{array}{l}\text { Using past successful green residential projects as } \\
\text { references }\end{array}$ & & & & & \\
\hline RMM14. & $\begin{array}{l}\text { Working with experienced insurance agent to receive } \\
\text { better coverage protection }\end{array}$ & & & & & \\
\hline
\end{tabular}

If there is any risk mitigation measure omitted by this questionnaire, please specify and assess it:

\section{References}

1. Zhao, X.; Hwang, B.G.; Gao, Y. A fuzzy synthetic evaluation approach for risk assessment: A case of Singapore's green projects. J. Clean. Prod. 2016, 115, 203-213. [CrossRef]

2. Ranaweera, R.; Crawford, R.H. Using Early-Stage Assessment to Reduce the Financial Risks and Perceived Barriers of Sustainable Buildings. J. Green. Build. 2010, 5, 129-146. [CrossRef]

3. Hwang, B.G.; Zhao, X.; See, Y.L.; Zhong, Y. Addressing Risks in Green Retrofit Projects: The Case of Singapore. Proj. Manag. J. 2015, 46, 76-89. [CrossRef]

4. Wu, P.; Xia, B.; Pienaar, J.; Zhao, X. The past, present and future of carbon labelling for construction materials-A review. Build. Environ. 2014, 77, 160-168. [CrossRef]

5. Wu, P.; Xia, B.; Zhao, X. The importance of use and end-of-life phases to the life cycle greenhouse gas (GHG) emissions of concrete-A review. Renew. Sustain. Energy. Rev. 2014, 37, 360-369. [CrossRef]

6. Energy and Cities: Sustainable Building and Construction. Available online: http://www.unep.or.jp/ietc/ focus/EnergyCities1.asp (accessed on 18 December 2016).

7. Zou, P.X.W.; Couani, P. Managing risks in green building supply chain. Archit. Eng. Des. Manag. 2012, 8, 143-158. [CrossRef]

8. Yang, R.J.; Zou, P.X.W. Stakeholder-associated risks and their interactions in complex green building projects: A social network model. Build. Environ. 2014, 73, 208-222. [CrossRef] 
9. Yang, R.J.; Zou, P.X.W.; Wang, J. Modelling stakeholder-associated risk networks in green building projects. Int. J. Proj. Manag. 2016, 34, 66-81. [CrossRef]

10. Zuo, J.; Zhao, Z.-Y. Green building research-current status and future agenda: A review. Renew. Sustain. Energy Rev. 2014, 30, 271-281. [CrossRef]

11. Qin, X.; Mo, Y.; Jing, L. Risk perceptions of the life-cycle of green buildings in China. J. Clean. Prod. 2016, 126, 148-158. [CrossRef]

12. Construction Statistics-GDP \& Productivity. Available online: https://www.bca.gov.sg/Infonet/constat. asp (accessed on 25 July 2016).

13. Building and Construction Authority. 3rd Green Building Masterplan; BCA: Singapore, 2014.

14. Academy-Courses-Certification Courses for Professionals/Specialists. Available online: https://www.bcaa. edu.sg/what-we-offer/courses/certification-courses (accessed on 26 August 2016).

15. Hwang, B.G.; Zhao, X.; Tan, L.L.G. Green building projects: Schedule performance, influential factors and solutions. Eng. Constr. Archit. Manag. 2015, 22, 327-346. [CrossRef]

16. Zhao, X.; Hwang, B.G.; Lee, H.N. Identifying critical leadership styles of project managers for green building projects. Int. J. Constr. Manag. 2016, 16, 150-160. [CrossRef]

17. Agarwal, S.; Satyanarain, R.; Sing, T.F.; Vollmer, D. Effects of construction activities on residential electricity consumption: Evidence from Singapore's public housing estates. Energ. Econ. 2016, 55, 101-111. [CrossRef]

18. Construction Statistics-Construction Output. Available online: https://www.bca.gov.sg/Infonet/constat.asp (accessed on 28 August 2016).

19. HDB Greenprint. Available online: http://www.hdb.gov.sg/cs/infoweb/about-us/our-role/smart-andsustainable-living/hdb-greenprint (accessed on 27 August 2016).

20. Punggol Eco-Town. Available online: http://www.hdb.gov.sg/cs/infoweb/about-us/our-role/smart-andsustainable-living/punggol-eco-town (accessed on 27 August 2016).

21. BCA Green Mark for New Residential Buildings. Available online: https://www.bca.gov.sg/greenmark/ others/gm_resi_v4.pdf (accessed on 26 June 2017).

22. BCA Green Mark for Existing Residential Buildings. Available online: https://www.bca.gov.sg/greenmark/ others/GMERB_v1.pdf (accessed on 26 June 2017).

23. Fortunato, B.R., III; Hallowell, M.R.; Behm, M.; Dewlaney, K. Identification of safety risks for high-performance sustainable construction projects. J. Constr. Eng. Manag. 2011, 138, 499-508. [CrossRef]

24. Sustainable Singapore Blueprint 2015. Available online: http://www.mewr.gov.sg/ssb/files/ssb2015.pdf (accessed on 24 June 2017).

25. Home-Technology-BCA Green Mark Scheme-Enhanced SGD 20 Million Green Mark Incentive Scheme for New Buildings (GMIS-NB). Available online: http:/ /www.bca.gov.sg/greenmark/gmis.html (accessed on 5 April 2016).

26. Home-Technology-BCA Green Mark Scheme-SGD 100 Million Green Mark Incentive Scheme for Existing Buildings (BMIS-EB). Available online: https://www.bca.gov.sg/GreenMark/gmiseb.html (accessed on 5 April 2016).

27. HDB Greenprint Brings Sustainable \& Green Living to 5800 Households in Teck Ghee. Available online: http:/ / www.hdb.gov.sg/cs/infoweb/press-releases/hdb-greenprint-brings-sustainable-and-greenliving (accessed on 27 August 2016).

28. Kelleher, J. HDB Greenprint@Yuhua Welcomes Singapore's First Green Neighborhood. Available online: http:/ / www.opengovasia.com/articles/6789-hdb-greenprint-yuhua-welcomes-singapores-firstgreen-neighbourhood (accessed on 27 August 2016).

29. Dewlaney, K.S.; Hallowell, M.R.; Fortunato, B.R., III. Safety risk quantification for high performance sustainable building construction. J. Constr. Eng. Manag. 2011, 138, 964-971. [CrossRef]

30. Tollin, H.M. Green building risks: It is not easy being green. Environ. Claim. J. 2011, 23, 199-213. [CrossRef]

31. Hwang, B.G.; Shan, M.; Tan, E.K. Investigating Reworks in Green Building Construction Projects: Magnitude, Influential Factors, and Solutions. Int. J. Environ. Res. 2016, 10, 499-510.

32. Hwang, B.G.; Shan, M.; Xie, S.; Chi, S. Investigating residents' perceptions of green retrofit program in mature residential estates: The case of Singapore. Habitat Int. 2017, 63, 103-112. [CrossRef]

33. BCA Directory-General Building. Available online: https://www.bca.gov.sg/BCADirectory/Search/Result? page $=-1 \&$ pCLSSelected $=, 83 \backslash \mathrm{T} 1 \backslash$ textbar $\{$ ALL\&pGrading=All\&d=1 (accessed on 18 June 2017). 
34. Akintoye, A. Analysis of factors influencing project cost estimating practice. Constr. Manag. Econ. 2000, 18, 77-89. [CrossRef]

35. Wu, P.; Low, S.P. Lean management and low carbon emissions in precast concrete factories in Singapore. J. Archit. Eng. 2011, 18, 176-186. [CrossRef]

36. Li, Y.Y.; Chen, P.H.; Chew, D.A.S.; Teo, C.C. Exploration of critical resources and capabilities of design firms for delivering green building projects: Empirical studies in Singapore. Habitat Int. 2014, 41, 229-235. [CrossRef]

37. Shan, M.; Chan, A.; Le, Y.; Xia, B.; Hu, Y. Measuring Corruption in Public Construction Projects in China. J. Prof. Issue Eng. Educ. Pract. 2015, 141, 05015001. [CrossRef]

38. Zou, P.X.W.; Zhang, G.; Wang, J. Understanding the key risks in construction projects in China. Int. J. Proj. Manag. 2007, 25, 601-614. [CrossRef]

39. Ke, Y.; Wang, S.; Chan, A.P.C.; Cheung, E. Understanding the risks in China's PPP projects: Ranking of their probability and consequence. Eng. Constr. Archit. Manag. 2011, 18, 481-496. [CrossRef]

40. Deng, X.; Pheng, L.S.; Zhao, X. Project system vulnerability to political risks in international construction projects: The case of Chinese contractors. Proj. Manag. J. 2014, 45, 20-33. [CrossRef]

41. Hwang, B.G.; Shan, M.; Supa'at, N.N.B. Green commercial building projects in Singapore: Critical risk factors and mitigation measures. Sustain. Cities Soc. 2017, 30, 237-247. [CrossRef]

42. Shan, M.; Chan, A.P.C.; Le, Y.; Hu, Y.; Xia, B. Understanding Collusive Practices in Chinese Construction Projects. J. Prof. Issue Eng. Educ. Pract. 2017, 143. [CrossRef]

43. Nunnally, J.C.; Bernstein, I.H.; Berge, J.M.T. Psychometric Theory; McGraw-Hill: New York, NY, USA, 1967.

44. Shiers, D.; Rapson, D.; Roberts, C.; Keeping, M. Sustainable construction: the development and evaluation of an environmental profiling system for construction products. Constr. Manag. Econ. 2006, 24, 1177-1184. [CrossRef]

45. Hwang, B.G.; Tan, J.S. Green building project management: Obstacles and solutions for sustainable development. Sustain. Dev. 2012, 20, 335-349. [CrossRef]

46. Robichaud, L.B.; Anantatmula, V.S. Greening project management practices for sustainable construction. J. Manag. Eng. 2010, 27, 48-57. [CrossRef]

47. Low, L. The political economy of migrant worker policy in Singapore. Asia Pac. Bus. Rev. 2002, 8, 95-118. [CrossRef]

48. Ong, Y. Singapore's Phantom Workers. J. Contemp. Asia 2014, 44, 443-463. [CrossRef]

49. Ogunlana, S.O.; Promkuntong, K.; Jearkjirm, V. Construction delays in a fast-growing economy: Comparing Thailand with other economies. Int. J. Proj. Manag. 1996, 14, 37-45. [CrossRef]

50. Hwang, B.G.; Leong, L.P. Comparison of schedule delay and causal factors between traditional and green construction projects. Technol. Econ. Dev. Ecol. 2013, 19, 310-330. [CrossRef]

51. Ameyaw, E.E.; Hu, Y.; Shan, M.; Chan, A.P.C.; Le, Y. Application of Delphi method in construction engineering and management research: A quantitative perspective. J. Civ. Eng. Manag. 2016, 22, 991-1000. [CrossRef]

52. Nair, S. Singapore Budget 2016: Foreign Worker Levy Increase Deferred in Marine and Process Sectors. Available online: http://www.straitstimes.com/business/economy/singapore-budget-2016foreign-worker-levy-increase-deferred-in-marine-and-process (accessed on 23 August 2016).

53. Home-Building Control \& Management-Legislation on Environmental Sustainability for Buildings. Available online: https://www.bca.gov.sg/EnvSusLegislation/Environmental_Sustainability_Legislation. html (accessed on 24 March 2016).

54. Ismail, S. 3 New Requirements for Buildings to Be Energy-Efficient. Available online: http: //www.channelnewsasia.com/news/singapore/3-new-requirements-for-bu/482052.html (accessed on 24 August 2016).

55. Pinto, J.K.; Slevin, D.P. Critical factors in successful project implementation. IEEE Tract. Eng. Manag. 1987, 1, 22-27. [CrossRef]

56. Cooke-Davies, T. The "real" success factors on projects. Int. J. Proj. Manag. 2002, 20, 185-190. [CrossRef]

57. Singapore: Leading the Way for Green Buildings in the Tropics. Available online: https://www.bca.gov.sg/ greenmark/others/sg_green_buildings_tropics.pdf (accessed on 24 June 2017).

58. Häkkinen, T.; Belloni, K. Barriers and drivers for sustainable building. Build. Res. Inf. 2011, 39, $239-255$. [CrossRef] 
59. Akintoye, A.S.; MacLeod, M.J. Risk analysis and management in construction. Int. J. Proj. Manag. 1997, 15, 31-38. [CrossRef]

60. Ford, D.N. Achieving multiple project objectives through contingency management. J. Constr. Eng. Manag. 2002, 128, 30-39. [CrossRef]

61. Thal, A.E., Jr.; Cook, J.J.; White, E.D., III. Estimation of cost contingency for air force construction projects. J. Constr. Eng. Manag. 2010, 136, 1181-1188. [CrossRef] 